\title{
Role of Capital Structure in Firm's Value: A Case of Pakistani Firms
}

\author{
MUHAMMAD ASIF \\ Assistant Professor, City University of Science and I.T, Peshawar \\ asifbaloch@cusit.edu.pk \\ MUHAMMAD USMAN HAMEED \\ MBA Student of City University of Science and I.T, Peshawar \\ ZAINULLAH KHALIL \\ Lecturer, City University Peshawar of Science and I.T, Peshawar
}

\begin{abstract}
The Most important and critical decision for a finance manager is adequate Capital structure. Modigliani and Miller had started the debate of capital structure in creating firm's value. The research was conducted to find out the impact of capital structure and the value of the firm in Pakistan. The research was conducted on 71 non-financial firms of KSE 100 index. Using fix effect regression in the study it was found that there is significant effect of Capital structure on firm's value but the use of debt financing had negative relationship with the firm's value.
\end{abstract}

Keywords: Capital structure, Firm's value, debt financing

\section{Introduction}

Capital structure is the mixture of debt and equity. The capital structure shows that how a firm finances its overall operations and growth by using different sources of funds (Horn, 2002). The debt financing is defined as, when a firm raises funds, by borrowing it from a creditor and receive a promise that the principal and interest on the debt has been repaid. It is done by selling bonds, bills, or notes to individual and/or institutional investors (Investopedia, 2014). The main advantages of debt financing are, First debt is the cheaper source of financing as compare to equity financing because the firm has to pay certain amount on a fix rate. One the other hand the shareholders always demand a high rate because as the owners of the firm they bear all the risk. Second, the debt financing provides the tax benefits. The interest on debt provides the tax shield (1-T) because interest is tax deductible (Brigham, 2003).Third, according to MM's signaling theory debt financing gives a positive signal in the market that firm's future prospects are bright. Due to debt financing financial risk will occur. By going for the debt financing investors think that mangers are confident about facing the risk. Therefore it gives a positive signal in the market (Brigham, 2003). The disadvantages of debt financing are First, debt financing increases an additional risk to the shareholders known as financial risk. Once a company go for debt financing it may default if it was unable to pay the 
interest payments. Due to this reason the shareholders demands increase their rate of return which in return increases the cost of capital (Pinto, 2010). Second in debt financing the company has to pay a series of fix amount for repayment of interest and principal. If the firm fails in payment it leads to bankrupt (Ascent capital, 2013).

The main disadvantages of equity financing are first, in equity financing, company will have to give up some control of their business. Investors not only share profits, they also involve in decision making. (For example through voting rights) Second, accepting investment funds from family or friends can affect personal relationships if the business fails. Other important thing is that there may be clashes in the decision making. Third, it takes time and money. The business may suffer if it has to spend a lot of time on investment strategies (business.qld, 2014). Fourth equity financing is expensive than the debt financing because as shareholders faces all the risk of the business, therefore they demand more than the bond holders (Brigham, 2003). Karachi Stock Exchange 100 Index (KSE-100 Index) was formed in November 1991. It was started with base points of 1000. It includes 64 top companies according to capitalization from each sector rest of 34 companies are selected according to the highest capitalization (Karachi Stock Exchange, 2014).

\subsection{Research Problem}

Although debt is considered as cheaper source of financing but in Pakistan there is a negative perception about the debt financing due to the following reasons, first is the element of interest (Riba) in the debt which is prohibited (Haram) according to the teachings of Islam. Second is the strict conditions on the loans by the banks, which is the main source of debt financing in Pakistan. Furthermore the bond market is not well developed in Pakistan. Modigliani and Miller in their research article in 1958 proved that capital structure has role in changing firm's value. But this theory was under certain assumptions .i.e. no Taxes, no bankruptcy cost, no brokerage fees, etc. There is a great variation in the previous studies therefore we cannot come up with a single answer

\subsection{Research Question}

- Is there a role of capital structure in creating firm's value in the case of Pakistani firms?

\subsection{Research Objective}

- To find out the effect of capital structure with special consideration on amount of debt financing in creating firm's value in the Pakistani Market.

- To find out effect of long term and the short term debt financing on the firm's value.

\section{Literature Review}

Before 1958 capital structure was considered irrelevance with value of the firm, however with the presentation of Trade-Off Theory by Franco Modigliani and Merton Miller (MM) the whole concept was changed. In their theory they said that debt financing up to a certain level provide tax shield (1-T) and here the bankruptcy cost makes no difference. This point is known as Threshold level of debt $D_{1}$. After this level the bankruptcy cost increases but it is less than the benefits of tax shield up to another level $\mathrm{D}_{2}$. At this level the capital structure is called the optimal capital structure. At this point 
the value of the firm is maximum (Brigham, 2003). Research conducted by Mohohlo in South Africa shows that South African firms follow the Pecking Order theory in their capital structure i.e. firms first use internal financing after this they go for external financing. Brigham (2003) shows that firms rely on long term debt rather than the short term debt. Most important result of the research is that there is no significance relationship between capital structure and value of the firm. The study was conducted on the non-financial firms listed in Johannesburg Stock Exchange (JSE) (Mohohlo, 2013). Lixin and Lin in their study on different companies of real estate sector listed in Shanghai Stock Exchange and Shenzhen Stock Exchange found that on average 55\% of total assets of the companies are financed by debt. Their study supports the concept of trade off theory i.e. by increasing the level of debt the firms' value increases (Lixin, 2008).

Research on 124 firms in Nigeria, Maxwell and Kehinde found that equity financing has a negative effect on value while long term debt financing has positive effect on firm's value. Therefore most of the financial managers in Nigeria advise to use the long term debt financing. These results support the pecking order theory (Maxwell, 2012). Eriotis and Vasiliou found in their research that 129 firms listed in Athens Stock Exchange (ASE) follow a Pecking Order in their capital structure. They further found that firms with high growth potential use less debt. Furthermore debt financing has negative impact on firm's growth i.e. the use of debt has negative effect on value of the firm (Eriotis, 2007). In another research by Hammada found that there is a negative relationship between capital structure and value of the firm. It further shows that the excess use of debt financing leads to decrease in the firms' value, as mentioned in the MM theory about the optimal debt level. The research was conducted on 18 non-financial services companies listed in Amman stock exchange (Hammmada, 2010). In study of finding the relationship of capital structure and firms value Masulis found that the change in debt level changes the share price of the firm i.e. the amount of debt had an effect on firm's value. However the study did not tell about the nature of relationship i.e. positive or negative Masulis (2011). Matarirano concluded in the research that use of debt financing with low interest rate adds more value than the debt with high interest rates. The research was conducted on small manufacturing firms in Bulawayo, Zimbabwe (Matarirano, 2007).

Masidonda and Idrus (n.a) found in their research that capital structure of a firm's value. They further found that long term debt financing increases the value of the firm because it gives tax benefit for long time (Masidonda, 2013). Arabahmadi and Arabahmadi (n.a) A in their research concluded that that the use of short term debt with lower interest rate is beneficial than the long term debt. Their research further supports the relationship of short term debt with ROE and profitability is positive while there is negative relationship in case of long term debt. The research was conducted on 252 nonfinancial companies listed in Tehran Stock Exchange (Arabahmadi, 2013). Ali. found in his research that the use of short term debt, enhances the firm's value rather than the use of long term debt. The long term debt financing is negatively related with growth and profitability i.e. it decreases the firm's value. The research was conducted on 75 Pakistani companies listed in Karachi stock exchange and 85 Indian companies listed in Bombay stock exchange (Ali, 2013). Study on life and non-life insurance companies of Pakistan 
by Naveed and Talat (2010) shows that the companies follow a pecking order pattern. It also shows that most of the companies depend upon the retained earnings or equity rather than debt financing. Further study describes the determinants of capital structure which are profitability, size of the firm, liquidity, tangibility and risk (Talat, 2010).

Jibran, Wajid, Waheed and Muhammad concluded in their research that Pakistani non-financial firms there are indications of pecking order theory in their capital structures but in the weak form. They reasons they found for this are, first the difficulties in raising the capital through financial markets because to get listed in a financial market require a lot of terms and conditions to be fulfilled. Second, the lack of investment culture in economy. Third most of the companies pay dividends therefore they have low retained earnings. The research was conducted on non-financial firms of Karachi Stock Exchange (Jibran, 2013). Umar (2012)and others in their research found that capital structure decision has important role in financial performance of the firm. They found that both short term and long term debt financing has negative impact on ROE. The research was conducted on 100 firms listed in Karachi stock exchange (Umar, 2012)

\subsection{Hypotheses}

The research has been conducted to check the following hypothesis

$H_{0}=$ Short Term Debt has negative relationship with $R O E$

$H_{0}=$ Long Term Debt has negative relationship with $R O E$

$H_{0}=$ Total Debt has negative relationship with $R O E$

$H_{0}=$ Profitability has negative relationship with Price of share

$H_{0}=$ Tangibility has negative relationship with Price of share

$H_{0}=$ Size has negative relationship with Price of share

$H_{0}=$ Growth has negative relationship with Price of share

$H_{0}=$ Tax Shield has negative relationship with Price of share

\section{Research Methodology}

\subsection{Data and Data Source}

Secondary data has been used which retrieved either from the annual reports of the firms and from KSE website. The research includes 71 non-Financial companies of KSE 100 Index. The purpose of choosing KSE 100 Index firms is that, these are firms with highest values in the market. Five years data of 2010-14 have been considered for research. Cross section analysis has been conducted by using Fix effect regression.

\subsection{Model of the Study}

In this research, to find out the relationship between capital structure and firm's value two models has been used.

\subsubsection{Model 1}

In this model different aggregate of debt financing is used i.e. short term debt, long term debt and total debt. Previous studies shows variation in results by using these variables. The model used in the research had also been used in the previous studies which include (Lixin, 2008), (Arabahmadi, 2013), (Saeed.M.M, 2013) and many others. With reasonable reforms the equation for the model is

$$
R O E=\alpha+\beta 1 S T D+\beta 2 L T D+\beta 3 T D
$$

Where in above equation $R O E$ is Return on equity, STD is Short term debt, LTD is Long term Debt and $T D$ is Total debt. 
In this model the depended variable is the Return on Equity (ROE) which is considered as a proxy for value of the firm. ROE is a key variable used as proxy for value of the firm by (Arabahmadi, 2013),(Lixin, 2008), (Wu.J, 2007) and others. ROE finds out what is the return of shareholder's investment and increasing the ROE will results in the increase in firm's value which is the goal of the firm (Ross, 2000). The Return on equity is calculated as

$$
R O E=\frac{\text { Net Income }}{\text { Total Shareholder Equity }}
$$

The independent variables are Short term debt, Long term debt and total debt. The purpose of using different types of debt financing is to make the results more reliable. Short Term debt is calculated as

$$
S T D=\frac{\text { Amout of Short Term Debt }}{\text { Total Capital }}
$$

Long Term debt is calculated as

$$
L T D=\frac{\text { Amout of Long Term Debt }}{\text { Total Capital }}
$$

Total debt is calculated as

\subsubsection{Model 2}

$$
T D=\frac{\text { Amout of Total Debt }}{\text { Total Capital }}
$$

Another model is been used to make the research more reliable. In this model the dependent variable is the price of the stock of the company which is considered as proxy for the firm's value. The independent variables in this model are the determinants of the capital structure which is considered as the proxy for the capital structure. These are the determinants of capital structure for a company proved by various researchers which includes (Ilyas, 2008), (Chen, 2003), (Samuel) and many others. These variables are Profitability, Tangibility, Size of the firm, Growth, Tax Shield. The equation for model is

$$
P=\alpha+\beta 1 P f+\beta 2 T+\beta 3 S+\beta 4 G+\beta 5 T s
$$

Where in above equation $P$ is Price of the share, $P f$ is Profitability, $T$ is Tangibility, $S$ is Size of the firm, $G$ is Growth and $T s$ is Tax Shield

In this model Price of the share is calculated as the average price of during the period. (Anup Chowdhury, 2010) In his research has also taken price as a proxy for firm's value. Share's price of company is one of the indicators of company's performance. For calculating Profitability, return on assets is used as proxy, which is calculated as

$$
\text { Profitability }=\frac{E B I T}{\text { Total Assets }}
$$

Tangibility has a huge effect on capital structure decision, as more company has tangible assets more it can borrow debt easily by keeping the tangible assets collateral (Buferna.2005), especially in case of Pakistan where bank loans are the main source of financing (Seikh, 2010). Tangibility is calculated as 


$$
\text { Tangibility }=\frac{\text { Total Tangibal Assets }}{\text { Total Assets }}
$$

Size of the firm is calculated as the natural log of book value of total assets. This method is also used by (Saeed, 2013) (Chen, 2003). Previous studies prove that size of the firm has major effect on capital structure decision (disused in Ch. 2) which ultimately effects firm's value.

$$
\text { Size }=\text { In (book value of total asset })
$$

Growth was calculated by different methods by different researches (Saeed, 2013) in their study calculated Growth as the percentage change in the value of assets i.e.

$$
\text { Growth }=\frac{\text { Assets of current year }- \text { Assets of previous year }}{\text { Assets of current year }}
$$

According to MM theory a certain level of debt financing provide tax shield and at optimal level the firm's value is Maximum (Brigham, 2003). Therefore considering the benefits, tax shield plays a vital role in both capital structure decisions and for sake of increasing firm's value. To calculate the Tax Shield, ratio of depreciation to total assets is used as a proxy.

\section{Analysis and Findings}

$$
\text { Tax Sheild }=\frac{\text { Depriciation }}{\text { Total Assets }}
$$

In model 1 the dependent variable is Return on equity (ROE) which has been considered as proxy for the value of the firm the independent variables are Short term debt, Long term debt and Total debt. The model 1 shows the following results

Table 4.1

\begin{tabular}{r|rrr} 
Source & SS & df & MS \\
\hline $\begin{array}{r}\text { Model } \\
\text { Residual }\end{array}$ & 9344.2929 & 3 & 3114.7643 \\
& 33317.9772 & 67 & 497.283241 \\
\hline Total & 42662.2701 & 70 & 609.461001
\end{tabular}

$\begin{array}{lr}\text { Number of obs }= & 71 \\ \mathrm{~F}(3, \quad 67) & =6.26 \\ \text { Prob }>\mathrm{F} & =0.0008 \\ \text { R-squared } & =0.2190 \\ \text { Adj R-squared } & =0.1841 \\ \text { Root MSE } & =22.3\end{array}$

The value of $\mathrm{R}$ square is 0.219 which shows the variance is $21.9 \%$. The value of adjusted $\mathrm{R}$ square is 0.1841 shows $18.41 \%$ contribution of Independent Variables in the Price of share. The significance value is 0.0008 which is less than 0.05 shows that the model is significant. 
the Price of share. The significance value is 0.0345 which is less than 0.05 shows that the model is significant.

Table 4.4

\begin{tabular}{r|rcccrr}
\hline price & Coef. & Std. Err. & $\mathrm{t}$ & $\mathrm{P}>|\mathrm{t}|$ & [95\% Conf. Interval] \\
\hline tangibility & -4.609979 & 7.934297 & -0.58 & 0.563 & -20.45586 & 11.23591 \\
size & 1.964324 & .7582682 & 2.59 & 0.012 & .4499575 & 3.47869 \\
taxshie1d & -147.3113 & 90.96559 & -1.62 & 0.110 & -328.9821 & 34.35951 \\
growth & -5.060963 & 15.47726 & -0.33 & 0.745 & -35.97119 & 25.84926 \\
profitabi1 y & .1442419 & .128748 & 1.12 & 0.267 & -.1128857 & .4013694 \\
cons & .8972951 & 3.683382 & 0.24 & 0.808 & -6.458928 & 8.253518 \\
\hline
\end{tabular}

The table 4.4 shows the coefficients. In this table the Beta value $\beta$ shows the percentage change in dependent variable by changing one unit of independent variable. The $\beta$ value for Tangibility is -4.61 which shows that there is negative relationship between Tangibility (I.V) and Share's price (D.V) i.e. by increasing one unit of tangibility there has been $461 \%$ decrease in price of share and vice versa. The calculated t value is 0.58 which is less than tabulated \pm 1.96 and the significance value is 0.566 greater than 0.05. Here null Hypothesis is accepted (i.e. $\mathrm{H}_{0}=$ Tangibility has negative relationship with Price of share). The $\beta$ value for Size of firm is 1.96 which shows that there is positive relationship between Size of firm (I.V) and Share's price (D.V) i.e. by increasing one unit of Size of firm there has been 196\% increase in price of share and vice versa. The calculated $t$ value is 2.589 which is greater than tabulated \pm 1.96 and the significance value is 0.012 less than 0.05 . Here the Null hypothesis is rejected (i.e. $\mathrm{H}_{0}=$ Size has negative relationship with Price of share). The $\beta$ value for Tax shield is -147 which shows that there is negative relationship between Tax shield (I.V) and Share's price (D.V) i.e. by increasing one unit of tangibility there has been $147 \%$ decrease in price of share and vice versa. The calculated $t$ value is -1.614 which is less than tabulated \pm 1.96 and the significance value is 0.111 greater than 0.05 . Here null hypothesis is accepted (i.e. $\mathrm{H}_{0}$ $=$ Tangibility has negative relationship with Price of share).

The $\beta$ value for Growth is -4.92 which shows that there is negative relationship between Growth (I.V) and Share's price (D.V) i.e. by increasing one unit of growth there has been $492 \%$ decrease in price of share and vice versa. The calculated $t$ value is -0.318 which is less than tabulated \pm 1.96 and the significance value is 0.751 greater than 0.05 . Here null Hypothesis is accepted (i.e. $\mathrm{H}_{0}=$ Growth has negative relationship with Price of share). Here the $\beta$ value for profitability is 0.143 which shows that there is positive relationship between profitability (I.V) and price of share (D.V) i.e. by increasing one unit of profitability there has been $14.3 \%$ increase in Share's price and vice versa. The calculated $\mathrm{t}$-value is 1.110 which is less than tabulated \pm 1.96 and the significance value is 0.271 greater than 0.05 . Here Null Hypothesis is accepted (i.e. $\mathrm{H}_{0}=$ Profitability has negative relationship with Price of share). 


\section{Conclusion}

The research is conducted on 71 non-financial firms of KSE 100 index. In this study multiple regression has been used. Two models have been used in the study for the purpose of attaining maximum accuracy in results. Both models conclude similar results. It was found that in a firm's value there is approximately $40 \%$ role of capital structure. The research did not support the positive impact of debt financing on firm's value both long and short term debt financing in a case of Pakistani firms.

\section{References}

Akthar, P., H. (2010). The determinants of capital structure: A case from Pakistan textile sector (Spinning Units). International Conference on Business Management, 18.

Ali, A. (2013, sep-Oct). Effect of capital structure on the performance of firms: Evidence from Pakistan and Indian stock market. IOSR Journal of Business and Management, 12(6), 83-93. Retrieved from www.iosrjournals.org

Anup, C., S., P. (2010, October). Impact of capital structure on firm's value: Evidence from Bangladesh. Business and Economic Horizons, 3(3), 119.

Arabahmadi, F. A. (2013). The relationship between capital structure and profitability (Case Study in Tehran Stock Exchange). Technical Journal of Engineering and Applied Science, 1787-1789. Retrieved from www.tjeas.com

Ascent capital. (2013). Retrieved from Ascent Capital LLC: http://www.ascentcapital.net/hello-world/

Buferna.F, B. H. (2005). Determinants of capital structure Evidence from Libya. University of Liverpool, Management Science, Liverpool.

Business.Qld. (2014). (The State of Queensland) Retrieved from http://www.business.qld.gov.au/business/starting/starting-a-business/fundingbusiness/equity-finance

Chen, J. J. (2003). Determinants of capital structure of Chinese-listed companies. Journal of business research, 1340-1352.

Eriotis, N. V. (2007). How firm characteristics affect capital structure: an empirical study. Managerial Finance, 33, 321-330. Retrieved from www.emeraldinsight.com/03074358.htm

Gemmill, G. (2001). Capital structure and firm value A study of split-capital closed-end funds in the UK. London.

Ghasemi, K. A. (2012). Studying the effect of debt ratio on market value of stock firms by using the liquidity. International conference on economics, trade and development (IPEDR), 36, 105,109.

Hammmada, A. (2010). Effect of capital structure on value of the firm. Master thesis, Yarmouk university, Bankinf and Finance, Jordan.

Jerald E. \& Pinto, E. H. (2010). Equity Asset Valuation (2nd ed.). John Wiley. Retrieved from http://books.google.com.pk/books?id=XCL9bkrOrpcC\&pg=PA74\&lpg=PA74\&dq=h ow+to+calculate+cost+of+equity+using+bond+yield+plus+risk+premium+approach $\&$ source $=$ bl\&ots $=6$ gf7 YeqlPh\&sig $=v Q i e 2 M n a 1 p-$ TXb6vISIklMID7I4\&hl=en\&sa=X\&ei=NXX4Uqu4GoOQhQe3poHQBg\&sqi=2\&ve $\mathrm{d}=0 \mathrm{CCQQ6}$ 
Jibran.S, W. W. (2013). Pecking at pecking order theory: evidence from pakistan's nonfinancial Sector. Journal of Competitiveness, 4(4), 86-95. doi: $10.7441 /$ joc.2012.04.06

Khan, G. (2009). The realtionship of capital structure decision with firm's performance: A Study of The Engineering Sector of Pakistan. COMSATS Institute of Information Technology, Department of Management Sciences, Vehari.

Lixin, L. (2008). The Relationship Between Debt Financing and Market Value of Company: Empirical Study of Listed Real Estate Company of China. Proceedings of the 7th International Conference on Innovation \& Management, 2047.

Masidonda, I. S. (2013). Determinants of capital structure and Impact capital structure on firm value. Journal of Business and Managemen, 7(3), 23-29. Retrieved from www.iosrjournals.org

Masulis, R. (2011). The Impact of Capital Structure Change on Firm Value. The Journal of Finance, 38, 107-126.

Matarirano. (2007). An Investigation into the Impact of Debt Financing on the Profitability of Small Manufacturing Firms in Bulawayo, Zimbabwe. Ronald H. Brown Institute for Sub-Saharan Africa 1st International Business Conference, (pp. 1-16). Pretoria.

Maxwell, K. (2012). Capital structure and firm value: empirical evidence from Nigeria. International Journal of Business and Social Science, 3, 256,257. Retrieved from www.ijbssnet.com

Mohohlo, N. (2013). The capital Structure and its impact on firm value of JSE Securities exchange Listed companies. Degree thesis, University of The Witwatersrand, Management, Johannesburg.

Onsomu. ( 2003). The relationship of debt financing and Value of the firms at nairobi stock exchange. University of nairobi, Management.

Pouraghajan, A. (2012). The Relationship between Capital Structure and Firm Performance Evaluation Measures: Evidence from the Tehran Stock Exchange. International Journal of Business and Commerce, 166-181.

Saeed.M.M, G. R. (2013). Impact of capital structure on banking performance (a case study of Pakistan). Interdisciplinary journal of contemporary research in business, 393404.

Seikh.N.A, W. (2010). Financing behavior of textile firms in Pakistan. International journal of innovation, management and technology, 1, 130-134.

Talat, A. A. (2010). Debt equity choice of life and non-life Insurers: evidence from Pakistan. 12.

Umar, M. T. (2012). Impact of Capital Structure on Firms' Financial Performance: Evidence from Pakistan. Research Journal of Finance and Accounting. Retrieved from https://www.academia.edu/6388725/Impact_of_Capital_Structure_on_Firms_Financi al_Performance_Evidence_from_Pakistan

Van Horn, J. W. (2002). Introduction to Financial management (12 ed.).

Velnampy, T. N. (2012). The Relationship between Capital Structure \& Profitability. Global Journal of Management and Business Research, 12(13), 72. 